\title{
Surimi of King Weakfish (Macrodon ancylodon) Wastes: Texture Gel Evaluation with Protease Inhibitors and Transglutaminase
}

\author{
Cláudio Rafael Kuhn ${ }^{1}$, Carlos Prentice-Hernández ${ }^{2}$, João Luís Vendruscolo ${ }^{3}$ and Germano \\ Jorge Dorneles Soares ${ }^{1 *}$ \\ ${ }_{1}$ Laboratório de Análises Bromatológicas e Bioquímicas - LABB; Departamento de Ciência e Tecnologia \\ Agroindustrial - DCTA; Faculdade de Agronomia 'Eliseu Maciel' - FAEM; Universidade Federal de Pelotas - \\ UFPEL; Campus Universitário; 96010-900; C. P. 354; germojds@ufpel.tche.br; Pelotas - RS - Brazil. ${ }^{2}$ Laboratório \\ de Tecnologia de Alimentos; Departamento de Química - DQM; Fundação Universidade Federal do Rio Grande - \\ FURG; Rio Grande - RS - Brazil. ${ }^{3}$ Empresa Brasileira de Pesquisa Agropecuária - EMBRAPA; Pelotas - RS - Brazil
}

\begin{abstract}
The protease inhibitors (bovine serum albumin -BSA - and egg white) and transglutaminase inhibitor $\left(\mathrm{NH}_{4} \mathrm{Cl}\right)$, was added to the surimi obtained by King weakfish (Macrodon ancylodon) wastes to evaluate your effect on the gel texture. Results indicated that the treatment with pre-heating $\left(60^{\circ} \mathrm{C}, 30 \mathrm{~min}+90^{\circ} \mathrm{C}, 15 \mathrm{~min}\right)$ favored the elasticity of the gel (ashi), demonstrating low proteolysis and characterizing the suwari phenomenon (high gel strength). Protease inhibitors increased gel strength significantly $(P<0.05)$ by compression force, when BSA was better than egg whites. Gels from surimi of King weakfish wastes didn't have action of the transglutaminase characterized.
\end{abstract}

Key words: Surimi, protease inhibitors, gel strength, transglutaminase

\section{INTRODUCTION}

The main characteristic of the surimi-based products is the ability to form the kamaboko gel. However, the gel formation can be affected by myofibril degradation (especially myosin), which occurs through the action of cathepsins and heat stable alkaline proteases which have not been fully removed during the surimi processing and activated by thermal treatment, characterizing the modori phenomenon (An et al., 1996; GarcíaCarreño, 1996). The denaturation of myosin heavy chain (MHC) is related with the increases of heating time, even though the pyrolysis of the fish muscle actomiosin doesn't happen below $100^{\circ} \mathrm{C}$.
Therefore, the MHC disappearance at initial heating stages $\left(40-60^{\circ} \mathrm{C}\right)$ only depends on the protein hydrolysis by proteases (Morrissey et al., 1993).

Myofibrils are susceptible to autolysis by the action of endogenous muscle proteinases, which can vary its activity according to the species, or even in the same fish species, depend on the habitat conditions what could interfer in inhibitor answer or in the mechanism of inhibition (An et al., 1994; Yongsawatdigul et al., 2000). For protecting network protein responsible for the gel formation many compounds of protein nature are used to improve the gel physical properties and control proteolysis, avoiding the myofibrils cleavage. These compounds are called protease

*Author for correspondence 
inhibitors and among them are used beef plasma proteins (BPP) or its fractions and egg whites, both fractions reach better effect than others proteins, like potato extracts or whey protein, for example (Kuhn and Soares, 2002). Compounds that reacting with sulphydryl groups were the most active inhibitors (Morrisey et al., 1993). Researches have demonstrated increase in gel strength by using protease inhibitors independently of fish species, but at different levels, as those found in Allaska pollock (Merluccius spp) and Pacific whiting (Merluccius productus) (Seymour et al., 1997; Yongsawatdigul et al., 2000).

In Brazilian fishery industries the king weakfish is traditionally used for filleting process and its wastes (carcasses) are only processed as fish flour. The exploitation of filleting process wastes to obtain surimi is a good alternative which avoids leavings and produces surimi base products with a high aggregate value and excellent nutritional characteristics (Kuhn and Prentice, 1999). In Brazil there are no assigned studies for surimi productions such as an adequate application of technology for those fish species found in fresh or salt water, which is an open field for scientific investigation and for fishery industries orientation. The mainly objectives of this work were: a) to verify the possible proteases presence in the gel of King weakfish wastes surimi; b) to evaluate the effect of the protease inhibitors bovine serum albumin (BSA) and egg white on the texture of the surimi gel and c) to characterize the transglutaminase action by addition of a specific inhibitor $\left(\mathrm{NH}_{4} \mathrm{Cl}\right)$ over the King weakfish wastes surimi.

\section{MATERIAL AND METHODS}

\section{Frozen surimi}

King weakfish (Macrodon ancylodon) carcasses were obtained from industrial processing fillets. Protease inhibitors bovine serum albumin (Sigma Chemical Co.), egg white (Fisher Scientific) and transglutaminase inhibitor, $\mathrm{NH}_{4} \mathrm{Cl}$ (Vetec Fine Chemical), cryoprotectants agents' sorbitol (Synth) and sodium tripolyphosphate (Synth) was used.

The raw material (carcasses) was processed into surimi following the model proposed by Kuhn and Prentice (1999). Head, viscera and tail were removed from fish carcasses and its backbones were quickly washed. The minced meat (pulp) was obtained by mechanical process separation with a Baader deboning machine (Baader mod. 694, with a drum of $5 \mathrm{~mm}$ of diameter perforations). Fresh mince was washed twice with cold water $\left(\mathrm{t}<10^{\circ} \mathrm{C}\right)$ in a ratio 3:1 (water: pulp, w/w) and slightly agitated during $5-7 \mathrm{~min}$ and drainage among the washes. After the second wash the pulp was refined by compression in drum steel with $2 \mathrm{~mm}$ diameter perforations. At last, the drainage operation for compression removed the pulp water excess to reach moisture levels between $70-75 \%$ (AOAC, 1995).The pulp was divided in three parts: control, pulp with BSA (1\%), and with egg white (3\%). The cryoprotectants agents (4\% sorbitol, $0.3 \%$ sodium tripolyphosphate) were also added in all samples. The product was frozen quickly $\left(-30^{\circ} \mathrm{C}\right)$ and stored at $-20^{\circ} \mathrm{C}$ until the gel preparation.

\section{Kamaboko gel preparation}

Surimi samples previously thawed were used for the gel preparation. The kamaboko gels formulations were: (G1) control; (G2) BSA 1\%; (G3) BSA, $1 \%$ and $\mathrm{NH}_{4} \mathrm{Cl}$ (Vetec Química Fina Ltda) 0.7\%; (G4) egg white 3\%; (G5) egg white (3\%) and $\mathrm{NH}_{4} \mathrm{Cl}(0.7 \%)$. All formulations contained $\mathrm{NaCl} 2 \%$ and starch (Synth Laboratories) 5\%. The batters (mixtures) were packed in $2.5 \mathrm{~cm}$ diameter tubes and heated at $90^{\circ} \mathrm{C}$ for $15 \mathrm{~min}(\mathrm{~A}), 90^{\circ} \mathrm{C}$ for $30 \mathrm{~min}(\mathrm{~B})$ and $60^{\circ} \mathrm{C}$ for $30 \mathrm{~min}$ followed by $90^{\circ} \mathrm{C}$ for $15 \mathrm{~min}(\mathrm{C})$. After cooking the tubes were removed and placed in a water bath and cooled at $4-5^{\circ} \mathrm{C}$ for $30 \mathrm{~min}$. All gels removed from the tubes were stored overnight at $4^{\circ} \mathrm{C}$, prior to testing.

\section{Texture profile analysis}

Kamaboko gels were evaluated in three replicate cylinders $(2.5 \mathrm{~cm}$ in diameter and height). They were cut for each treatment and subjected to instrumental analysis, using an Instron Universal Testing Machine (Instron, mod. 1130) for compression tests and cohesiveness. The force required for a specified degree of compression of its original length was reported in grams (g); cohesiveness was calculated as the ratio of the peak of the second compression curve to the peak of first compression curve. Samples of kamaboko gels were subjected to compression in $1 / 4$ of their original length (axial axes) using a crosshead speed and chart of $10 \mathrm{~cm} \cdot \mathrm{min}^{-1}$ and a load cell of 50kg (Soares and Arêas, 1995; Boye and Lanier, 1988; Arêas and Lawrie, 1984). 


\section{Moisture determination}

Moisture was determined by drying (5.0 g sample) at $105 \pm 3^{\circ} \mathrm{C}$, in hot air oven in three repetitions (AOAC, 1995).

\section{Statistical analysis}

The analysis of variance (ANOVA) using the Duncan's test at $95 \%$ of significance into 45 treatments (5 formulations x 3 heating times $\times 3$ replicates) was carried out. The software used was the Statistica 5.0 for Windows (Statsoft, 1998).

\section{RESULTS AND DISCUSSION}

\section{Cohesiveness}

Results demonstrated alterations on the gel matrix by the presence of protease inhibitors and by heating treatment (Table 1). Statistical analysis showed that the thermal treatment was significant $(p<0.05)$, independent of formulation reaching a larger elastic texture (ashi).

Table 1 - Cohesiveness ${ }^{1}$ values to the King weakfish wastes surimi (Macrodon ancylodon)

\begin{tabular}{c|c|c|c}
\hline Gel Formulation** & \multicolumn{3}{|c}{ Heating* } \\
\cline { 2 - 4 } & A & B & C \\
\hline G1 & $0.7431 \mathrm{a}$ & $0.7382 \mathrm{~b}$ & $0.8038 \mathrm{a}$ \\
G2 & $0.8205 \mathrm{a}$ & $0.7018 \mathrm{~b}$ & $0.7728 \mathrm{a}$ \\
G4 & $0.7899 \mathrm{a}$ & $0.7420 \mathrm{~b}$ & $0.7866 \mathrm{a}$ \\
G5 & $0.8128 \mathrm{a}$ & $0.6698 \mathrm{~b}$ & $0.7487 \mathrm{a}$ \\
\hline
\end{tabular}

Mean values at the lines not proceeded by the same letter they differ to each other for Duncan's test $(\mathrm{p}<0.05)$. CV $($ Covariance - Total $)=0,4046 \% * \mathrm{~A}=90^{\circ} \mathrm{C}, 15 \mathrm{~min} ; \mathrm{B}=90^{\circ} \mathrm{C}, 30 \mathrm{~min} ; \mathrm{C}=60^{\circ} \mathrm{C}, 30 \mathrm{~min}+90^{\circ} \mathrm{C}, 15 \mathrm{~min}$. ** Gel formulations: G1, control; G2, with $\mathrm{BSA}$; 3 , with $\mathrm{BSA}+\mathrm{NH}_{4} \mathrm{Cl}$; $\mathrm{G} 4$, with egg white; G5, with egg white $+\mathrm{NH}_{4} \mathrm{Cl}$.

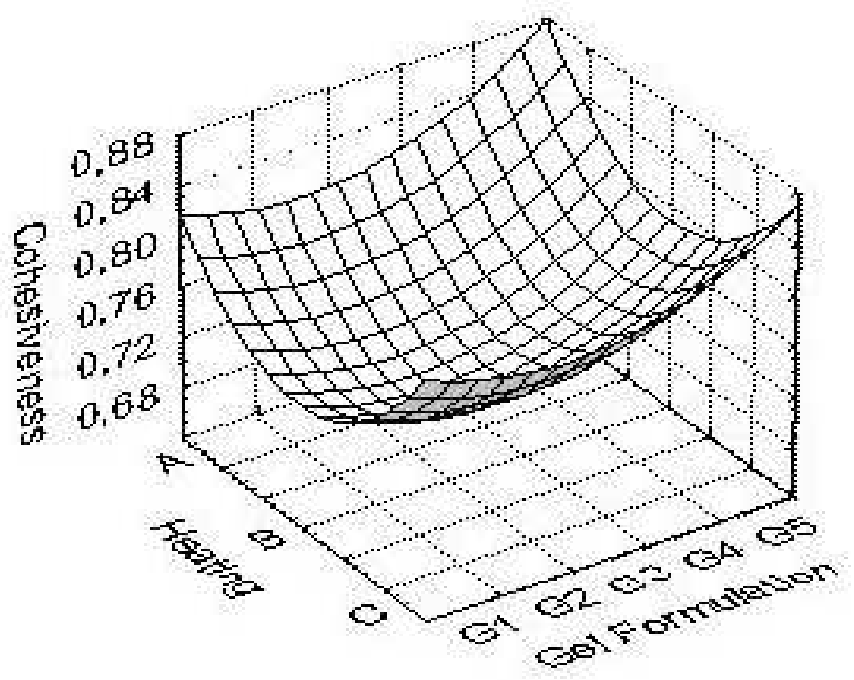

Figure 1 - Characterization of the cohesiveness from surimi gels of King weakfish wastes (Macrodon ancylodon) at different treatments.

The heating treatments ' $\mathrm{A}$ ' $\left(90^{\circ} \mathrm{C}, 15 \mathrm{~min}\right)$ and ' $\mathrm{C}$ ' (pre-heating at $60^{\circ} \mathrm{C}, 30 \mathrm{~min}+90^{\circ} \mathrm{C}, 15 \mathrm{~min}$ ) were more indicate to better kamaboko gel cohesiveness from King weakfish (Fig. 1). However, the more prolonged cooking time, at the high temperature
('B' treatment using $90^{\circ} \mathrm{C}$ for $30 \mathrm{~min}$ ) caused larger damage to the gel matrix. This excessive thermal denaturation could explain the lower values of cohesiveness observed for all gel formulations. 
The pre-heating thermal treatment results induce a better protein conformation, characterizing the 'setting' phenomenon (suwari), with an absence of proteolysis in the kamaboko gel of King weakfish wastes.

This behavior to the gel formation was also observed in salmon (Salmo salar), which had temperature setting among $40-60^{\circ} \mathrm{C}$ by heating up to $30 \mathrm{~min}$ (Saeki et al., 1995). Probably by extension of the heating time, besides $30 \mathrm{~min}$, that myofibrillar proteolysis (modori) from King weakfish should be better characterized as such happened in Atlantic menhaden (Brevoortia tyrannus) that presented proteolysis at heating times of $90-120 \mathrm{~min}$ for $60^{\circ} \mathrm{C}$ (Boye and Lanier, 1988).
The best cohesiveness results on the gels with inhibitors in King weakfish wastes surimi also indicated a protecting action of these compounds on the myofibril structure improving its functionality. Pacific herring (Clupea harengus pallasii) gels also presented this tendency where the suwari was favored by the employment of same inhibitors (Reppond et al., 1995).

\section{Compression}

Compression force $(\mathrm{kg})$ significantly increased $(\mathrm{P}<0.05)$ at the presence of protease inhibitors BSA and egg white (Table 2) preserving the main protein characteristic, the ability for jelling forming under heating.

Table 2 - Compression force (g) in gels from King weakfish wastes surimi (Macrodon ancylodon).

\begin{tabular}{c|ccccc}
\hline \multirow{2}{*}{ Heating* } & \multicolumn{5}{|c}{ Gel Formulation** } \\
\cline { 2 - 6 } & G1 & G2 & G3 & G4 & G5 \\
\hline \multirow{2}{*}{ A } & $1866,67 \mathrm{c}$ & $2255.00 \mathrm{~b}$ & $3208.33 \mathrm{a}$ & $2325.00 \mathrm{~b}$ & $2483.33 \mathrm{~b}$ \\
B & $2225.00 \mathrm{c}$ & $2433.00 \mathrm{~b}$ & $3026.67 \mathrm{a}$ & $2515.00 \mathrm{~b}$ & $2446.67 \mathrm{~b}$ \\
C & $2116.67 \mathrm{c}$ & $2751.67 \mathrm{~b}$ & $2866.67 \mathrm{a}$ & $2620.00 \mathrm{~b}$ & $2533.33 \mathrm{~b}$ \\
\hline
\end{tabular}

Mean values at the lines not proceeded by the same letter they differ to each other for Duncan's test $(\mathrm{p}<0.05){ }^{*} \mathrm{~A}=90^{\circ} \mathrm{C}$, $15 \mathrm{~min} ; \mathrm{B}=90^{\circ} \mathrm{C}, 30 \mathrm{~min} ; \mathrm{C}=60^{\circ} \mathrm{C}, 30 \mathrm{~min}+90^{\circ} \mathrm{C}, 15 \mathrm{~min}$. $* *$ Gel Formulations: G1, control; G2, with BSA; G3, with $\mathrm{BSA}+\mathrm{NH}_{4} \mathrm{Cl}$; $\mathrm{G} 4$, with egg white; $\mathrm{G} 5$, with egg white $+\mathrm{NH}_{4} \mathrm{Cl}$.

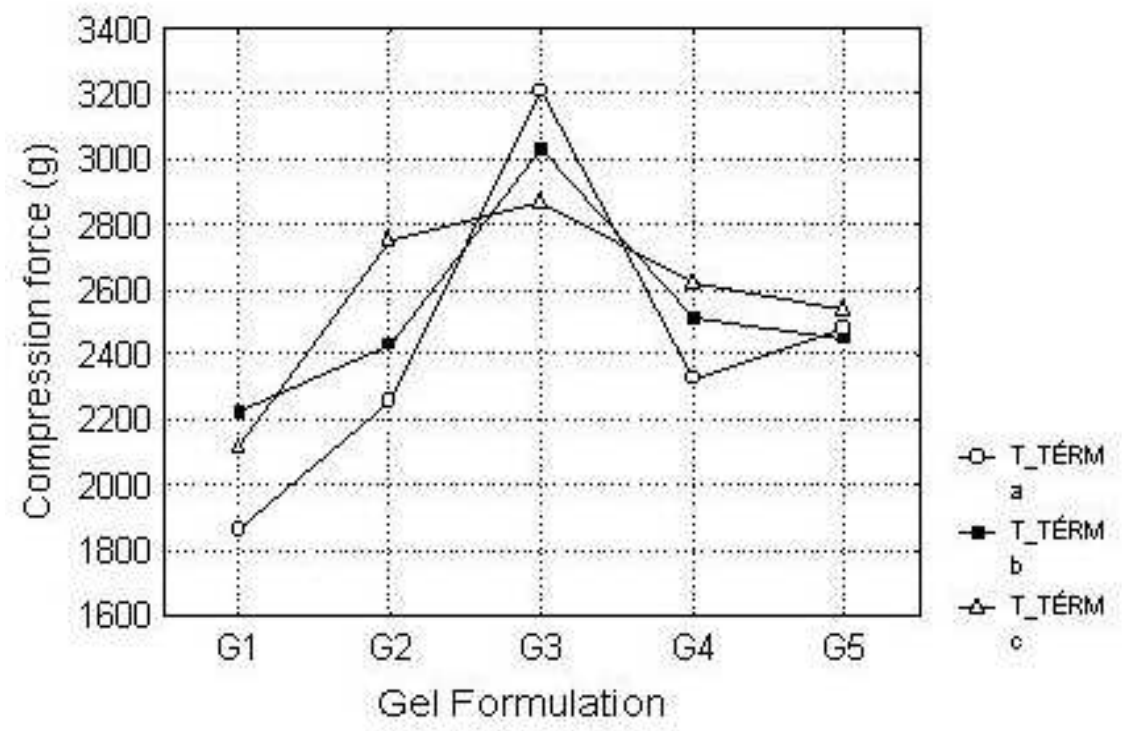

Figure 2 - Gel strength at compression force (g) from King weakfish wastes surimi (Macrodon ancylodon). 
The results demonstrated that treatment 'G3' (BSA as inhibitor and greater salt concentration, with $\mathrm{NaCl} 2.0 \%+\mathrm{NH}_{4} \mathrm{Cl} 0.7 \%$ ) was the most effective, reaching a compression force over $3.0 \mathrm{~kg}$ (Fig. 2). The remaining treatments although significantly better in comparison to control (G1), did not obtain difference themselves $(\mathrm{P}<0.05)$.

The kamaboko gels from King weakfish surimi without inhibitors (control) have presented high compression force $(>2.0 \mathrm{~kg}$ ) likely to Atlantic menhaden (Brevoortia tyrannus) gels at the same conditions (Boye and Lanier, 1988). The gel strength average of surimi from tilapia (Oreochomis sp) in compression tests reached $1.0 \mathrm{~kg}$ although using hydrocolloids (Barreto and Beirão, 1999).

The heat stability of BSA can explain its best acting because of the fraction $\gamma$-globulin, which demands larger denaturation temperature (Raeker and Johnson, 1995). The BSA combined to a bovine plasma fraction (globulin fraction, FIV-1) demonstrated that the increase of gel strength heatinduced it was higher than BSA only, suggesting a synergic interaction between BSA and the fraction $\alpha_{2}$-macroglobulin $\left(\alpha_{2}-\mathrm{M}\right)$. However, BSA could be form an own gel in higher concentrations $(>4 \%)$ by increasing in the disulfide bonds and contributing to the gel stability (Seymour et al., 1997).

The increase in gel strength of King weakfish wastes surimi contends egg whites was due to ovostatin presence that has molecular structure and function homologous to $\alpha_{2}-\mathrm{M}$ (Weerasinghe et al., 1996). Ovostatin inhibited in a non-competitive way the proteases cathepsin-D, tripsin, quimiotripsin and colagenase, controlling your activity of these and other enzymes. In spite of be a macromolecule its use in surimi is possible due to membrane absence in altered muscular tissue, which can impede its penetration (Ashie and Simpson, 1996).

The egg white also contributes to increase the gel strength by your coagulating capacity specially the ovoalbumin. The phenomenon occurs together with the starch gelation used in kamaboko gels and leads an increase in the viscosity of batter which prevents the coalescence of the air cells inside the structure, increasing volume without contribute to the your stability (Kuhn and Soares, 2002).

\section{Salt concentration}

The salt concentration was decisive to change the proteins conformation increasing the electrostatic interactions and hydrophobic forces. In the Fig. 2, was evidenced that the bigger compression force is reached in the largest saline concentration and using BSA as inhibitor ('G3' treatment, using $\mathrm{NaCl} 2.0 \%+\mathrm{NH}_{4} \mathrm{Cl} 0.7 \%$ ). When the myosin is joined in the muscle it's have a stronger proteinprotein interaction with low ratio superficial area/volume turning it insoluble. When the salt is introduced, positive and negative ions links to opposite loads and they break the ionic bonds (Lin and Park, 1998). In agreement with Niwa (1992) the break of the interactions intra and intermolecular of the proteins by the ionic force provides an structure unfolding and exposing sulphydryl groups before occult for own native conformation with an increase in its exhibition and oxidation where disulfide bonds are forming and the protein structure stabilized.

\section{Tranglutaminase inhibitor}

When present in muscle, transglutaminase produces the gel stability by the cross-links formation of the protein molecules and increasing the surimi gel strength (Lee et al., 1997; Morales et al., 2001). $\mathrm{NH}_{4} \mathrm{Cl}$ is an enzyme specific inhibitor and can stop the transglutaminase action with the gel not reaching higher texture (Kumazawa et al., 1995; Morales et al., 2001). The kamaboko gels of King weakfish wastes with $\mathrm{NH}_{4} \mathrm{CL}$ have no decrease in gel strength. The observed behavior of gels was different from Alaska Pollock (Merluccius spp) where gel strength reductions were higher than $50 \%$ using $\mathrm{NH}_{4} \mathrm{Cl}$ as enzyme inhibitor (Kumazawa et al., 1995). Therefore, the largest compression force in the treatments containig $\mathrm{NH}_{4} \mathrm{Cl}$ indicated the absence of the action of the enzyme on the kamaboko gels from King weakfish wastes.

\section{ACKNOWLEDGEMENTS}

1. Indústria de Pescado Furtado S/A, to available equipments and facilities;

2. Torquato Pontes Pescados Ltda., by supply the raw material;

3. Programa de Pós-graduação em Ciência e Tecnologia Agroindustrial da Faculdade de Agronomia 'Eliseu Maciel', Universidade Federal de Pelotas (UFPel), Fundação Universidade Federal do Rio Grande, RS (FURG) and Empresa Brasileira de Pesquisa Agropecuária - EMBRAPA, Clima Temperado, by avaialable laboratories for the 
chemical analysis, surimi processing and accomplishment the instrumental analysis respectively

4. FAPERGS and CAPES by financial support and to $\mathrm{CNPq}$ for the concession of the scholarships.

\section{RESUMO}

Os inibidores de protease (soro albumina bovina BSA e clara de ovo) e o inibidor de transglutaminase $\left(\mathrm{NH}_{4} \mathrm{Cl}\right)$, foram adicionados ao surimi elaborado com resíduos do processamento de filetagem da pescada-foguete (Macrodon ancylodon) para avaliar seus efeitos sobre a textura do gel. Os resultados de coesividade indicaram que o tratamento com pré-aquecimento $\left(60^{\circ} \mathrm{C}, 30\right.$ $\min +90^{\circ} \mathrm{C}, 15 \mathrm{~min}$ ) favoreceu a elasticidade do gel, demonstrando pouca atividade proteolítica e caracterizando o 'suwari'. A utilização dos inibidores de protease aumentou significativamente $(\mathrm{P}<0.05)$ a força de compressão, com o inibidor BSA superior à clara de ovo. Nos géis de surimi de resíduos da pescadafoguete não foi caracterizada ação da enzima transglutaminase.

\section{REFERENCES}

An, H.; Peters, M. Y. and Seymour, T. A. (1996), Roles of endogenous enzymes in surimi gelation. Trends in Food Science and Technology, 7, 321-326.

An, H.; Seymour, T. A.; Wu, J. and Morrissey, M. T. (1994), Assay systems and characterization of Pacific Whiting (Merluccius productus) protease. J. of Food Science, 59, 277-281.

AOAC (1995), Official Methods of Analysis. Association of Official Agricultural Chemists. $14^{\text {th }}$ ed. Editorial Board.

Arêas, J. A. G. and Lawrie, R. A. (1984), Effect of lipid - protein interactions on extrusion of offal protein isolates. Meat Science, 7, 275-299.

Ashie, I. N. A. and Simpson, B. K. (1996), $\alpha_{2}-$ Macroglobulin inhibition of endogenous proteases in fish muscle. J. of Food Science, 61, 357-361.

Barreto, P. L. M. and Beirão, L. H. (1999), Influência do amido e carragena nas propriedades texturais do surimi de Tilápia (Oreochomis SP.). Ciência $e$ Tecnologia de Alimentos, 19, 183-188.

Boye, S. W. and Lanier, T. C. (1988), Effects of heatstable alkaline protease activity of Atlantic menhaden (Brevoortia tyrannus) on surimi gels. J. of Food Science, 53, 1340-1342.
García-Carreño, F. L. (1996), Proteinase inhibitors. Trends in Food Science and Technology, 7, 197-204.

Kuhn, C. R. and Prentice-Hernández, C. (1999), Estudo tecnológico para obtenção de surimi utilizando resíduos do processamento de pescada-foguete (Macrodon ancylodon), Cap. 06, In: Prêmio Jovem Cientista: Oceanos, Fonte de Alimentos. Rio de Janeiro : CNPq. pp. 181-211. [Publicação dos trabalhos vencedores].

Kuhn, C. R. and Soares, G. J. D. (2002), Proteases e inibidores no processamento de surimi. Revista Brasileira de Agrociência, 8, 5-11.

Kumazawa, Y.; Numazawa, K.; Seguro, K. and Motoki, M. (1995), Suppression of surimi gel setting by transglutaminase inhibitors. J. of Food Science, 60, 715-717, 726.

Lee, H. G.; Lanier, T. C. and Hamann, D. D. (1997), Covalent cross-linking effects on thermo-rheological profiles of fish protein gels. J. of Food Science, 62, 25-28, 32.

Lin, T. M. and Park, J. W. (1998), Solubility of Salmon myosin as affected by conformational changes at various ionic strengths and $\mathrm{pH}$. J. of Food Science, 61, 432-438.

Morales, O. G.; Ramírez, J. A.; Vivanco, D. I. and Vázquez, M. (2001), Surimi of fish species from Gulf of México: evaluation of the setting phenomenon. Food Chemistry, 75, 43-48.

Morrissey, M. T.; Wu, J. W.; Lin, D. and An, H. (1993), Protease inhibitor effects on torsion measurements and autolisys of Pacific whiting surimi. J. of Food Science, 58, 1050-1054.

Niwa, E. (1992), Chemistry of surimi gelation, In: Lanier, T. C. and Lee, C. M. (Eds.). Surimi Technology, Ch 16. New York : Marcel Dekker, Inc. pp. 389-428.

Raeker, M. Ö. and Johnson, L. A. (1995), Thermal and functional properties of bovine blood plasma and egg white proteins. J. of Food Science, 60, 685-690,706.

Reppond, K. D.; Babbitt, J. K.; Bernsten, S. and Tsuruta, M. (1995), Gel properties of surimi from Pacific herring. J. of Food Science, 60, 707-710,714.

Saeki, H.; Iseya, Z.; Sugiura, S. and Seki, N. (1995), Gel forming Characteristics of frozen surimi from chum salmon in the presence of protease inhibitors. J. of Food Science, 60, 917-928.

Seymour, T. A.; Peters, M. Y.; Morrissey, M. T. and An, H. (1997), Surimi gel enhancement by bovine plasma proteins. J. of Agric. and Food Chem, 45, 2919-2923.

Soares, G. J. D. and Arêas, J. A. G. (1995), Effect of Electrical Stimulation on Post mortem Biochemical Characteristics and Quality of Longissimus dorsi thoracis Muscle from Buffalo (Bubalus bubalis). Meat Science, 41, 369-379.

Statsoft Inc (1998), Statistica for windows (Computer program manual). Tulsa, OK, USA. 
Werasinghe, V. C.; Morrissey, M. T. and An, H. (1996), Characterization of active components in food-grade proteinase inhibitors for surimi manufacture. $J$. of Agric. and Food Chem., 44, 2584-2590.

Yongsawatdigul, J.; Park, J. W.; Virulhakul, P. and Viratchakul, S. (2000), Proteolytic degradation of tropical tilapia surimi. J. of Food Science, 65, 129-133.

Received: August 06, 2003; Revised: March 04, 2004;

Accepted: July 09, 2004 